\title{
Chronic Hypertension During the First Trimester of Pregnancy: What is New About the Use of Angiotensin- Converting Enzyme Inhibitors?
}

\author{
Lucas Soares Bezerra ${ }^{1 *}$, Marcelo Antônio Oliveira Santos-Veloso ${ }^{1}$ and Sandro Gonçalves de Lima ${ }^{1,2}$ \\ ${ }^{1}$ Maurício de Nassau University, Brazil \\ ${ }^{2}$ Federal University of Pernambuco, Brazil
}

*Corresponding author: Lucas Soares Bezerra, Maurício de Nassau University, Recife, Pernambuco, Brazil.

Received Date: February 15, 2019

Published Date: February 20, 2019

\section{Introduction}

Cardiovascular diseases are a major cause of maternal mortality and morbidity worldwide, including developed countries [1]. The first-line drug to treat hypertension in pregnant women is methyldopa, which is an $\alpha 2$-adrenergic agent that has shown maternal and fetal safety and efficacy. However, methyldopa is not effective in all cases, and sometimes it is important to consider other pharmacological agents $[1,2]$.

Angiotensin-converting enzyme inhibitors (ACEIs) are effective first-line antihypertensive drugs, with additional benefit in diabetic subjects [3]. Also, a positive effect to prevent dementia has been reported, especially in patients with diabetes or hypertension [4]. ACEIs are contraindicated during the second and third trimesters of pregnancy due to well-recognized congenital malformations, such as the renin-angiotensin-system (RAS) blockade syndrome [2,3]. Most part of guidelines and studies contraindicate ACEI use during the first trimester of pregnancy [5,6]. Nevertheless, actual risks are not fully cleared in literature, especially because hypertension represents an isolated risk factor for malformations, and in some of those studies the sample presented comorbidities such as diabetes, which were important confounding factor in the analysis of fetal outcomes risk [3,7-9].

Studies about the use of ACEIs during the early pregnancy have been presenting conflicting results $[10,11]$. Therefore, this work intends to discuss about the state-of-the-art of this subject.

\section{Discussion}

In 2006, an important cohort study was performed with 29,057 infants, in which 209 had ACEIs exposure alone during the first trimester [7]. The study found those with only first-trimester exposure to ACEI presented an increased risk for teratogenicity (Relative Risk - RR, 2.71; 95\% Confidence Interval - CI, 1.72 to 4.27) when compared to infants who had no exposure to antihypertensive agents. Fetus exposure to other class for antihypertensive drugs, however, did not show increased risk of malformations (RR, 0.66; $95 \% \mathrm{CI}, 0.25$ to 1.75 ). This work was the main responsible for influencing further research evaluating the risks of the ACEIs in first-trimester pregnancy.

Nevertheless, a few important limitations and biases limits the validity of those results [11]. For example, women with undiagnosed diabetes or diet-controlled were included in the same sample with no adjustments for pre-pregnancy body mass, which is a considerable confounding bias, due to its known fetal malformations increased risk [8,9]. The most common fetal malformations and complications due to ACEIs use are described in the Table 1.

Table 1: Common fetal malformations and complications related to ACEls use in early pregnancy $[1,2,5,12,13]$.

\begin{tabular}{|c|c|}
\hline Malformations & Complications \\
\hline Craniofacial deformations & Renal failure \\
\hline Skull and lung hypoplasia & Anuria \\
\hline Cardiovascular & Oligohydramnios \\
\hline
\end{tabular}

According to a systematic review conducted by Bullo et al. [12], including 37 articles, $52 \%$ of newborns exposed to ACEIs had no complications $(\mathrm{P}=0.0001)$. Despite of that, the study did not present the prevalence of complications in case of ACEIs intake during the first trimester only. Thus, the prevalence of newborns diagnosed with fetal RAS-blockade syndrome was significantly lower in those exposed at the beginning of pregnancy only $(\mathrm{P}=0.05)$. 
Comparing the use of ACEIs during the first trimester, a cohort study performed with 1,333,624 pregnancies, from those 4,107 was exposed to ACEIs, showed a prevalence of malformations in $5.9 \%$ of cases compared with $3.3 \%$ in the unexposed group [3].
However, the $\mathrm{CI}$ of the risk ratios has crossed the null hypothesis [1], which implies that in some situations the outcome presented no differences between the studied groups as detailed in Table 2 .

Table 2: Studies published in the last five years analyzing fetal outcomes after the use of ACEls during the first trimester of pregnancy in comparison to control groups: unexposed versus antihypertensive drugs or exposed to methyldopa.

\begin{tabular}{|c|c|c|c|c|c|c|c|c|c|c|}
\hline \multirow[t]{2}{*}{ Author, Year } & \multirow[t]{2}{*}{ Country } & \multirow[t]{2}{*}{$\begin{array}{l}\text { Sample } \\
\text { Size }\end{array}$} & \multicolumn{4}{|c|}{ Unexposed versus ACEI } & \multicolumn{4}{|c|}{ Methyldopa versus ACEI } \\
\hline & & & Malformations & Prevalence & $\begin{array}{c}\mathrm{RR} / \mathrm{OR} / \\
\mathrm{HR}\end{array}$ & $95 \% \mathrm{CI}$ & $\begin{array}{l}\text { Malforma- } \\
\text { tions }\end{array}$ & $\begin{array}{l}\text { Preva- } \\
\text { lence }\end{array}$ & $\begin{array}{c}\mathrm{RR} / \\
\mathrm{OR} / \mathrm{HR}\end{array}$ & $95 \% \mathrm{CI}$ \\
\hline Bateman et al. [3] & USA & 4,107 & $\begin{array}{l}\text { No increased } \\
\text { risk }\end{array}$ & $\begin{array}{c}3.3 \% \dagger \text { versus } \\
5.9 \%^{*}\end{array}$ & RR 0.89 & $\begin{array}{c}0.75- \\
1.06\end{array}$ & - & - & - & - \\
\hline Ahmed et al. [13] & Australia & 67 & - & - & - & - & $\begin{array}{l}\text { No in- } \\
\text { creased risk }\end{array}$ & - & $\begin{array}{l}\text { OR } 0.5^{\mathrm{a}} \\
\text { OR } 0.6^{\mathrm{b}}\end{array}$ & $\begin{array}{l}0.2-1.1^{\mathrm{a}} \\
0.2-1.3^{\mathrm{b}}\end{array}$ \\
\hline $\begin{array}{c}\text { Hoeltzenbein et al. } \\
{[10]}\end{array}$ & Germany & 329 & Increased risk & $\begin{array}{c}3.4 \% \dagger \text { versus } \\
5.5 \%^{*}\end{array}$ & OR 2.38 & $\begin{array}{l}1.03- \\
5.49\end{array}$ & $\begin{array}{l}\text { No in- } \\
\text { creased risk }\end{array}$ & $\begin{array}{c}3.7 \% \dagger \\
\text { versus } \\
4.7 \% *\end{array}$ & OR 1.47 & $\begin{array}{c}0.53- \\
1.31\end{array}$ \\
\hline
\end{tabular}

Abbreviations: $\mathrm{Cl}$, confidence interval; $\mathrm{CM}$, cardiac malformation; $\mathrm{HR}$, hazard ratio; OR, odds ratio; NM, neurological malformation; RR, relative risk; USA, United States of America. a preterm birth; b low body weight; *ACEIs; †control.

A different cohort study analyzed the use of ACEIs compared to methyldopa.13 As result, no increased risk for preterm birth was found due to the use of ACEIs or in the low body weight group. Also, no increased risk was found in a German cohort (4.7\% ACEIs vs $3.7 \%$ methyldopa) [10].

It is important to consider that hypertension might be an independent risk factor to the development of fetal malformations $[13,14]$ as demonstrated in a cohort study conducted by Bateman, et al. [15] According to Bateman, patients under antihypertensive drug treatment had a higher risk of any congenital anomalies (OR, 1.7; 95\% CI, 1.6-1.9), as well those with untreated chronic hypertension (OR, 1.5; 95\% CI, 1.4-1.6), when compared to a control group.

Actually, the American College of Obstetricians and Gynecologists does not recommend the prescription of ACEIs in women at reproductive age, except when there are compelling reasons (i.e. presence of proteinuric renal disease) $[13,16]$. Considering the studies published in the last few years, the majority of cases of ACEIs use was not associated with increased risk of fetal malformations $[3,13]$. except for one study that found increased risk of major birth defects when compared to patients unexposed to antihypertensive drugs (5.5\% ACEIs vs 3.4\% unexposed) [10].

Despite that, in all three studies included in the Table 2, the CI for risk crossed the null hypothesis. In those scenarios, the outcome is the same in both groups so the ratio results in one, which implies that there is no difference between the two arms of the studies.

Considering the data available in literature, we believe that at this point there is no evidence enough to support the use of ACEIs during the first trimester of pregnancy. Neither the association with fetal anomalies is fully established and understood nor the real benefits of ACEIs prescription, except in strict scenarios. Also, it seems reasonable and safer to suspend ACEIs prescription at early pregnancy, considering the risk of inadequate prenatal follow-up, and the risk of ACEI continuation during the second or third trimester of pregnancy.

\section{Acknowledgement}

None.

\section{Conflict of Interest}

No conflict of interest.

\section{References}

1. Pieper PG (2015) Use of medication for cardiovascular disease during pregnancy. Nat Rev Cardiol 12(12): 718-729.

2. Pucci M, Sarween N, Knox E, Lipkin G, Martin U (2015) Angiotensinconverting enzyme inhibitors and angiotensin receptor blockers in women of childbearing age: risks versus benefits. Expert Rev Clin Pharmacol 8(2): 221-231.

3. Bateman BT, Patorno E, Desai RJ, Seely EW, Mogun H, et al. (2017) Angiotensin-converting enzyme inhibitors and the risk of congenital malformations. Obstet Gynecol 129(1): 174-184.

4. Kuan YC, Huang KW, Yen DJ, Hu CJ, Lin CL, et al. (2016) Angiotensinconverting enzyme inhibitors and angiotensin II receptor blockers reduced dementia risk in patients with diabetes mellitus and hypertension. Int J Cardiol 220: 462-466.

5. de Oliveira MH, Costa EN, Toscano PR, Tedoldi CL (2009) Fármacos cardiovasculares na gestação e amamentação in - Diretriz da Sociedade Brasileira de Cardiologia para Gravidez na Mulher Portadora de Cardiopatia. Arq Bras Cardiol 93(supl.1): 120-126.

6. Malachias M, Souza W, Plavnik F, Rodrigues C, Brandão A, et al. (2016) $7^{\text {a }}$ Diretriz brasileira de hipertensão arterial. Arq Bras Cardiol 107(3Supl 3): 1-83.

7. Cooper WO, Hernandez-Diaz S, Arbogast PG, Dudley JA, Dyer S, et al. (2006) Major congenital malformations after first-trimester exposure to ACE inhibitors. N Engl J Med 354(23) :2443-2451.

8. Ornoy A, Reece EA, Pavlinkova G, Kappen C, Miller RK (2015) Effect of maternal diabetes on the embryo, fetus, and children: congenital anomalies, genetic and epigenetic changes and developmental outcomes. Birth Defects Res Part C Embryo Today 105(1): 53-72.

9. Abell SK, Nankervis A, Khan KS, Teede HJ (2016) Type 1 and Type 2 diabetes preconception and in pregnancy: health impacts, influence of obesity and lifestyle, and principles of management. Semin Reprod Med 34(2): 110-120. 
10. Hoeltzenbein M, Tissen-diabaté T, Fietz A, Zinke S, Kayser A, et al. (2018) Increased rate of birth defects after first trimester use of angiotensin converting enzyme inhibitors-Treatment or hypertension related? An observational cohort study. Pregnancy Hypertens 13: 65-71.

11. Morton AP (2013) Are angiotensin-converting enzyme inhibitors and angiotensin 2 receptor blockers teratogenic? Diabet Med 30(10): 1263 1265.

12. Bullo M, Tschumi S, Bucher BS, Bianchetti MG, Simonetti GD (2012) Pregnancy outcome following exposure to angiotensin-converting enzyme inhibitors or angiotensin receptor antagonists. Hypertension. 60(2): 444-650.

13. Ahmed B, Tran DT, Zoega H, Kennedy SE, Jorm LR, et al. (2018) Maternal and perinatal outcomes associated with the use of renin-angiotensin system (RAS) blockers for chronic hypertension in early pregnancy. Pregnancy Hypertens 14: 156-161.

14. Ramakrishnan A, Lee LJ, Mitchell LE, Agopian AJ (2015) Maternal hypertension during pregnancy and the risk of congenital heart defects in offspring: a systematic review and meta-analysis. Pediatr Cardiol 36(7): 1442-1451.

15. Bateman BT, Huybrechts KF, Fischer MA, Seely EW, Ecker JL, et al. (2014) Chronic hypertension in pregnancy and the risk of congenital malformations: a cohort study. Am J Obstet Gynecol 212(3): 1-14.

16. American College of Obstetricians and Gynecologists; Task Force on Hypertension in Pregnancy (2013) Hypertension in pregnancy. Report of the American College of Obstetricians and Gynecologists' Task Force on Hypertension in Pregnancy. Obs Gynecol 122(5): 1122-1131. 